\title{
A leap to the digital era-what are lower and upper secondary school students' experiences of distance education during the COVID-19 pandemic in Serbia?
}

\author{
Tünde Kovács Cerović ${ }^{1}$ - Katarina Mićić ${ }^{1}$ (D) S Selena Vračar $^{2}$ \\ Received: 26 October 2020 / Revised: 30 March 2021 / Accepted: 8 April 2021 / \\ Published online: 29 April 2021 \\ (C) Instituto Universitário de Ciências Psicológicas, Sociais e da Vida 2021
}

\begin{abstract}
The aim of this paper is to thoroughly examine how students in Serbia experienced their education through distance learning during the 2020 Spring school closures due to the pandemic. Schoolchildren's multigenre narratives about learning during school closure were elicited by online surveys; qualitative thematic and values analyses were conducted; and data was further analysed by cluster analysis, ANOVA, and $t$-tests. A total of 45 lower and upper secondary school students produced 106 narratives providing 429 thought units for analysis. Altogether, 6 themes and 26 value codes were identified. They demonstrate the wide range, complexity, and nuanced positioning of students' experiences towards the new situation, their role in it, and the role of others i.e. teachers and the technology itself. The paper draws implications on the policy and educational-psychological and methodological level.
\end{abstract}

Keywords School closure $\cdot$ COVID-19 $\cdot$ Narrative analysis $\cdot$ Distance learning $\cdot$ Dynamic storytelling

"Dear friend from another country, it looks like you will be starting distance education, I have already gone through it. It was not terrible, each week became more challenging, each task more demanding, each homework more and more extensive, with the worst that the curriculum got increasingly difficult, without a teacher to explain it appropriately (...). Sometimes you will maybe feel empty, alone, stupid, even depressed, but do not let this prevent you from moving on, do not let it prevent you from enjoying your life, even if it is hard. Maybe this isn't really encouraging, but you have to know that you are not alone"

Katarina Mićić

katarina607@gmail.com

1 Faculty of Philosophy, University of Belgrade, Belgrade, Serbia

2 Faculty of Media and Communications, Singidunum University, Belgrade, Serbia 
This letter was written by a 12-year-old boy in Serbia during school closure in Spring 2020. It expresses an experience shared by 1.5 billion children, as over $90 \%$ of students globally were enrolled in distance schooling in the course of 2020 (UNESCO, 2020). School closure due to the COVID-19 pandemic created unprecedented changes in the ecology of schooling, leaving children isolated from peers and their entrenched social milieu, rupturing routines and transforming support systems, and creating new pedagogies mediated by technology.

Distance learning is by no means a new education model (see Bates, 1993; Rumble, 2001). The transition to emergency distance learning in 2020 was so massive, abrupt, and unpreparedfor, that it is questionable if the body of prior knowledge developed on distance education can shed any light on it. Moving to distance education for all students and all teachers, at the same time, in an emergency situation is different than organizing it for interested students and wellprepared teachers. The context, speed, and magnitude of the shift to online teaching ruptured the network of usual support systems: parents and teachers who were supposed to mediate this situation for children were confused themselves with sudden changes, as were school leaders and school governors (Bubb \& Jones, 2020).

Education in the "new normal" of the pandemic has become a novel and dynamic field of research. One research line attempts to capture the diverse organizational formats of (predominantly higher) education, examination, and assessment (e.g. Tartavulea et al., 2020), including detecting challenges for students such as lack of digital equipment or balancing responsibilities (e.g. Adnan \& Anwar, 2020; Bal et al., 2020). Another line focuses on teachers - their coping mechanisms, managing burnout risk, and transformative experiences (among others Hargreaves \& Fullan, 2020; Kim \& Asbury, 2020; Moss et al., 2020).

A third line of research and thinking revolves around collecting evidence and analysing diverse country responses and draws recommendations on best practices and ways to avoid pitfalls (Dhawan, 2020; OECD, 2020; Reimers \& Schleicher, 2020). Thinking about the school closure crisis and "chaos" as an opportunity to reimagine the future (Azorín, 2020) and as a possible catalyst for educational change (Zhao, 2020) is a further constructive step in looking at the effects of the COVID-19 crisis in education, one that could prompt a rethinking of the what, how, and where of education in the future.

Research building on school-age student voices is still rare. Studies with children have most often been restricted in scope to one locality or neighbourhood, derived from developed countries with high ICT literacy and involved digitally competent students, while many new studies of children's perceptions seem to be still forthcoming (see Fickermann \& Edelstein, 2021). Their voices are mostly heard in the context of investigation by journalistic (Hilppö et al., 2020) or children's rights' organisations (e.g. UNICEF, 2020) or by students' organizations themselves (e.g. Union of Highschool Students of Serbia, 2020). Albeit rare, scholarly explorations of student perceptions are of utmost importance for understanding the complexity of the situation and could hopefully spotlight areas needing urgent remedy. Research tapping into student wellbeing has detected the manyfold concerns of children during the 2020 Spring lockdown, including fears of getting sick, depression, and loneliness (e.g. Kirsch et al., 2020). Other studies focused on challenges with covering the curriculum and completing multiplying assignments. Niemi and Kousa (2020) compared students' and teachers' perceptions of distance learning and found that, even after a prolonged period, teachers still failed to acknowledge how demanding and overwhelming distance education was for their students. A study of more than 2000 school students in Austria by Pelikan et al. (2021) also reported that students found emergency distance education more demanding than regular school with "too many assignments to complete in too little time" and highlighted the importance of self- 
regulation skills in order to master the increased requirements on their own. Bubb and Jones (2020) analysed factors leading to satisfaction with the innovative and creative character of online education in a community in Norway, through gathering assessments from school students, teachers and parents.

Our study is focused exclusively on the - hitherto mostly lacking — students' perceptions of education in the time of lockdown. While all perspectives are relevant, we focused on schoolchildren out of policy, educational-psychological, and theoretical reasons. We deemed the "new normal" not as a paralyzing experience but as an inherently human situation: one of challenging boundaries, where a new context (schooling from home) and a new tool (distance learning media and platforms) called for a renegotiation of the roles and expectations of all actors involved, and for engaging in a process of co-constructing the meaning of what is happening. In the process of this co-construction, for lack of the possibility to actually participate in the virtual interactions of the key actors, we opted for asking schoolchildren about their experiences. We expected that their accounts could have implications on education policy options and decisions at political levels, especially regarding the organization of schooling. We also expected that schoolchildren's expressions could guide educational psychologists and school leaders in setting up and nurturing support systems for students, modulating expectations of them, and providing space for autonomy and development in the most unusual schooling situation as well. Finally, we assumed that the structure and dimensions of the way that students made sense of the unwanted situation could be of value per se and help us improve our understanding of the children's unique perspective and intricate knowledge about education, themselves, their teachers, peers, the new technology tools and the encounter with a completely unknown experience.

We sought answers to the following questions: how did children experience the abrupt change from regular to distance schooling and make sense of it? What can we learn from their voices? What recommendations can we draw for future schooling in the time of pandemic? These research questions guided our exploration of schoolchildren's narratives about education during the first school lockdown in Spring 2020 in Serbia - an issue that has become even more relevant with further waves of the pandemic.

\section{Context of the Study}

As in many other European countries, schools in Serbia shut down in mid-March. School closure was immediately coupled with restrictive lockdown measures, such as a 5 p.m. -5 a.m. curfew on weekdays and total ban on movement over weekends, subsumed under a state of emergency called on March 15th. The state of emergency and the curfew were abolished in early May, but schools reopened only with the start of the new school year on September 1st, leaving 3 full months of instruction to be conducted via distance learning. A critical piece was provided by TV instruction ${ }^{1}$, organized via 3 channels of public TV and broadcasting three or four 30-min prerecorded lectures for each grade each day, according to a predetermined schedule and with rotating teachers for each subject (Ministry of Education, Science, and

\footnotetext{
${ }^{1}$ Broadcasting live lessons or existing prerecorded material in order to provide continuity in education was endeavored worldwide. All but one country in Eastern Europe and Central Asia, and around 60\% of countries in Western Europe, employed TV lessons in remote schooling generally along with different digital platforms, https://en.unesco.org/covid19/educationresponse/nationalresponses
} 
Technological Development of the Republic of Serbia, 2020a, 2020b). In total, around $85 \%$ of students made use of this means of instruction (Institute of psychology, 2020). TV instruction was complemented by teacher-led instruction via distance learning platforms or social media, chosen and organized according to teachers' decisions (Ministry of Education, Science, and Technological Development of the Republic of Serbia, 2020a). According to PISA 2012 (Pavlovic Babic \& Baucal, 2013), digital literacy of Serbian students seems to be higher than their other measured competencies. Also, technical prerequisites for distance learning did not pose a particularly striking problem in Serbia. Among teachers, 97\% had Internet access at home, and $85 \%$ had computers they could use for online teaching, and $99 \%$ of school-age student population had a working digital device and Internet access (Institute of psychology, 2020). Additionally, the government, NGOs, and private companies arranged distribution of digital devices and learning platforms, and internet access was provided free of charge $^{2}$. Nevertheless, technical capacities did not guarantee a high-quality delivery of online instruction-we expect that some of the results of our research will address this question as well.

\section{Methods}

Our approach is based on qualitative analysis of children's narratives about school closure elicited by online prompts, further quantified and analysed by cluster analysis, ANOVA, and $t$-tests.

Schoolchildren experienced a dynamic, loosely structured, and unexpected situation affecting their lives and surroundings. As a data collection methodology, narratives have a great potential to convey striking, fuzzy, or emergent experiences, also allowing us to capture their dynamic contradictions (Bamberg, 2004; Zittoun, 2006). In addition, in order to fully capture the narrative's dialogical potential (Bakhtin, 1986), we decided to use the dynamic storytelling approach (Daiute \& Kovač-Cerović, 2017), with three narrative genres to prompt expressive accounts about the experience of learning during school closure. As prior research shows, dynamic storytelling design provides a reliable method for integration of diverse stakeholders around issues requiring interventions of policy, practice, and research (Daiute \& Kovač-Cerović, 2017; Daiute, 2008, 2013), as well as eliciting hard-to-access areas of experience such as discrimination and segregation (Daiute \& Kovač-Cerović, 2017), or migration (Kovac Cerovic et al., 2018; Daiute et al., 2020). Participants use diverse genres to enact different aspects of their knowledge, experience, and goals and thus provide a complex range of engagements with their environments for their own sense-making and to inform others about ongoing challenges, strategies, and successes in their situations. Writing a story involves an exploration of characters situated in time and space, writing a letter conveys a purposeful selection of own experiences and reflections to share with someone, while writing a request involves a direct expression to a stated audience (individual, group, role), involving reference to norms and expectations, and placing the author in a position of authority (Daiute \& Kovač-Cerović, 2017).

\footnotetext{
${ }^{2}$ Information on the availability of technology for teachers and the undertaken measures were obtained from the Ministry of Education, Science, and Technological development upon request.
} 


\section{Participants}

A total of 45 students, aged 12-18 (Table 1) responded to an online request to write about their experience of school lockdown. The link to the online prompt was distributed via school psychologists and teachers who had online contact with students, and participation was fully voluntary. The selection of participants was guided by the maximum variation principle (Creswell \& Poth, 2016) - we aimed to gather a sample of participants diverse in terms of age, gender, educational level, and school type, from both urban and rural settlements in Northern, Central, and Southern Serbia. The sample of 45 respondents is well inside the size brackets for samples used in the most cited narrative studies in education (Guetterman, 2015). However, the sample was biased in favour of students who had the technology to access the online survey and the skills to independently respond.

\section{Instrument}

The survey was administered in May and June 2020, when the state of emergency was lifted, but schools were still closed. It consisted of two types of items - open-ended prompts for creating narratives and multiple-choice questions for demographic and educational variables.

In order to elicit narratives in accordance with the dynamic storytelling approach described above (Daiute \& Kovač-Cerović, 2017), the prompt for the story was: "Please write a story about an event that happened to a child during distance learning due to the pandemic. It can be a story you experienced, or just heard about", for the letter: "Write a letter to a peer in a country where school closure is yet to come. Write about what to expect, what to look out for", and for the request: "Imagine there was a box where you could put your suggestions to teachers about distance learning". Demographic and educational variables were city/town, type of school, age, and gender. Responses were anonymous and arrived directly to the researchers, without being mediated by teachers or school psychologists.

\section{Analyses}

The students produced 106 narratives: 36 stories, 31 letters, and 39 requests; most students chose to express their experiences in two genres (Table 2).

The 106 narratives were first segmented into thought units (usually one unit per sentence), a total of 429. Using an inductive approach (Patton, 2002), we first identified themes and then conducted a thorough values analysis (Daiute, 2013). The three researchers collaboratively read $10 \%$ of the texts to develop a coding manual; applied the manual individually for the next $10 \%$, based on which they adjusted and fine-tuned the manual ${ }^{3}$; and coded another $10 \%$ individually for a coding reliability check. Cohen's kappa coefficient showed strong agreement between two coders $(\kappa=0.85, p=.000)$. The remaining $70 \%$ of the texts were further coded individually by the two junior researchers by using the ATLAS.ti 9 software.

Subsequent analyses included a hierarchical cluster analysis to obtain the metanarrative structure (Greenhalgh et al., 2005) and $t$-test and ANOVA for looking into differences in value distribution for demographic variables and three genres. Most of the statistical analyses were conducted on narrative product level data (narrative products being the units of observation), and for some analyses, we used data aggregated on the level of participant. In both cases, input data were binarized, expressing whether

\footnotetext{
${ }^{3}$ The Coding Manual can be obtained from the authors upon request.
} 
Table 1 Sample of students by gender and school type

\begin{tabular}{lllll}
\hline & Elementary school & General secondary school & Vocational school & Total \\
\hline Female & 9 & 8 & 13 & 30 \\
Male & 10 & 2 & 3 & 15 \\
Total & 19 & 10 & 16 & 45 \\
\hline
\end{tabular}

each value code occurred or not in the given narrative product or by the given participant. This mitigated the effect of length of narratives, since girls and older students tended to write more elaborately, which could confound clustering and comparison analyses.

\section{Results}

The analysis of narratives identified 6 themes and 26 value codes, demonstrating the wide range, nuance, and depth of the experiences that students chose to share.

The coding system is illustrated in the story, requests, and letters below, written by the Serbian students in our sample. These examples also contextualize some of the most frequent codes identified in our analysis.

A boy, age 13 recalls the unusual and demanding experience of using different technologies at the start of online education in his story, reflects about his feelings and concerns, and weighs the pros and cons of the new experience:

The event I will remember is the beginning of online education and learning from home [PIO-Unusal_way_of_learning]. It was very hard for me to get used to all that, in the school everything was different [PIO-Unusal_way_of_learning]. The first day was the hardest, I had to follow the online instruction, and, in parallel, to do homework sent by the teachers [PIO-Demanding], while I didn't have experience with Google classroom, Edmodo and emails [T-Dominating_instruction]. I didn't know how to use them [REFLSelf_evaluation], and I was afraid that I would fail [REFL-Anxiety]. It was bad that we had to learn in a short time how to use all this, and to do our homework simultaneously [REFL-Feeling_overwhelmed], but it was good that we mastered the use of all these applications and now we are much more computer and internet literate [TPotential_for_learning].

Table 2 Narrative products by genre, school type, and gender

\begin{tabular}{lllll}
\hline & Requests & Stories & Letters & Total \\
\hline Elementary school & 15 & 18 & 17 & 50 \\
Female & 8 & 9 & 8 & 25 \\
Male & 7 & 9 & 9 & 25 \\
Gymnasium & 9 & 8 & 9 & 26 \\
Female & 7 & 7 & 8 & 22 \\
Male & 2 & 1 & 1 & 4 \\
Vocational school & 15 & 10 & 5 & 30 \\
Female & 12 & 8 & 5 & 25 \\
Male & 3 & 2 & 0 & 5 \\
Total & 39 & 36 & 31 & 106 \\
\hline
\end{tabular}


A letter by a girl, age 16, to her peers airs a multitude of self-reflections in providing advice on how to cope with the demanding learning situation incurred during distance education, including self-evaluation, self-regulation, and coping:

A lot of learning and homework is awaiting you [PIO-Demanding]. You will have many tests, some of which you will not understand, since you did not learn the material [REFL-Self_evaluation]. Get ready to study diligently [REFL-Self_regulation] and ask teachers for help if you do not understand something [REFL-Self_regulation], if you do not clarify what you don't understand right away, it will get more difficult later [PIOTemporal_dimension]. Think about how the next school year will be easier, exactly because you learnt a lot during the time of online schooling [REFL-Coping].

Another letter by a girl, age 13, shares her advice focused on coping strategies in the expectation of demanding and challenging schooling during lockdown:

You should be calm, because you will get used to everything, [REFL-Coping], you will get the hang of it [REFL-Coping]. Of course, you should prepare for the tasks, assessments, work assignments, exercises, tests [REFL-Self_regulaation]. Brace yourself for hard work [PIO-Demanding]. Also, you should be prepared to follow all lectures, because who knows what the teacher will ask you to do [REFLSelf_regulaation].

A request to teachers by a girl, age 16, echoes some of the concerns mentioned in the previous letter, but sturdily puts the spotlight also on the teachers' role in creating a more thoughtful and rich learning environment and better organization for all:

I often didn't like that we were overloaded with information [PIO-Demanding]. Sometimes we received documents with long and incomprehensible text full of useless definitions [PIO-Demanding], and we didn't know what to select and study from these [REFL-Self_evaluation] because we didn't have live classes [PIOUnusal_way_of_learning]. I would change and make that part more concise, instead of the traditional text I would create a breathtaking presentation with visual effects and maybe some interactive details, although even a somewhat more colorful and better elaborated text would be sufficient [PIO-Active_and_creative_use_of_ICT]. Also, I would like it if all teachers used only one service for conveying information, at least in the same school, so that students could detect all the information easier, and could more easily and quickly adapt to the platform used, so that this process would not last for a month or so [PIO-Organisational_problems].

Another request to teachers by a boy, age 12 , is pinpointing organizational problems:

There should be less homework [PIO-Demanding]. They should align TV broadcasting with the school curriculum [PIO-Organisational_problems]. The class schedule should be followed and homework assignments should be given accordingly [PIOOrganisational_problems].

On the general level of the identified themes, the results show that not all themes were detected in the narratives of all students participating in the research. Table 3 provides the percentages 
Table 3 Percentage of students who mention each theme

\begin{tabular}{lc} 
Theme & Percentage \\
\hline Experience of lockdown (EL) & $22 \%$ \\
Perception of the instruction and obligations (PIO) & $87 \%$ \\
Perception of teachers (PT) & $51 \%$ \\
Reflections (REFL) & $84 \%$ \\
Support for learning (SfL) & $22 \%$ \\
Use of technology (T) & $42 \%$ \\
\hline
\end{tabular}

of students who mention each individual theme. This distribution of themes shows the relevance of the themes chosen by our methodology, but it also forefronts the most important results of our research and directs towards a more detailed analysis at the level of particular values identified at the level of narrative units.

The frequencies and percentages for all identified themes and values in the narrative units are presented in full detail in Fig. 1, showing that two themes dominated the narratives. Over one-third of all units coded the students' diverse perceptions of the instruction and obligations (38\%) often expressed in the stories, while over a quarter of the units coded some aspect of the students' self-reflection (27\%), many expressed through the letters. Among perceptions of instruction and obligations, most prominent were those that emphasized how demanding (or not demanding) the instruction was and how unusual it was. Emphasis of reflections was distributed more evenly on different aspects, such as positive feelings, anxiety, and selfevaluation, with the importance of self-regulation stressed much more often. All other themes were registered in less than $10 \%$ of units, and albeit conveying important value statements students chose to share through the narratives, codes had low frequencies.

\section{Cluster analysis of narratives}

In order to capture and organize this diversity of perceptions, experiences, interpretations, and reflections in the expressions of schoolchildren, we applied a hierarchical clustering using Ward's linkage method and squared Euclidean distance on the binarized aggregated narrative product data.

In the cluster analysis of the stories, the letters, and the requests detected in each case, two interrelated but were very broad clusters, but the joint cluster analysis of all texts provided a clearer picture. See the dendrogram on Fig. 2.

The cluster analysis detected altogether three clusters that serve to group the 6 themes and 26 values identified by the inductive value analysis into three metanarratives. The metanarratives set the stage for a highly unusual learning experience; describe the nuanced modes of the student's feelings, thoughts, and actions when confronted with an extraordinary challenge; and provide a dynamic representation of the "other" (teacher, technology, or both) with whom students engage in dialogue through their narratives, about the common experience. To express their perception of the learning context (cluster 1), students refer to a multitude of organizational problems and share pleas for more thoughtful organization of instruction and tasks. "Harmonize TV broadcasting and the school curriculum", "Expect a general breakdown of the system" or "Get ready, you will have thousands of codes to access some platforms, prepare a lot of patience". They emphasize how demanding were the instruction and tasks, referring to "materials overcrowded with information". Students often 


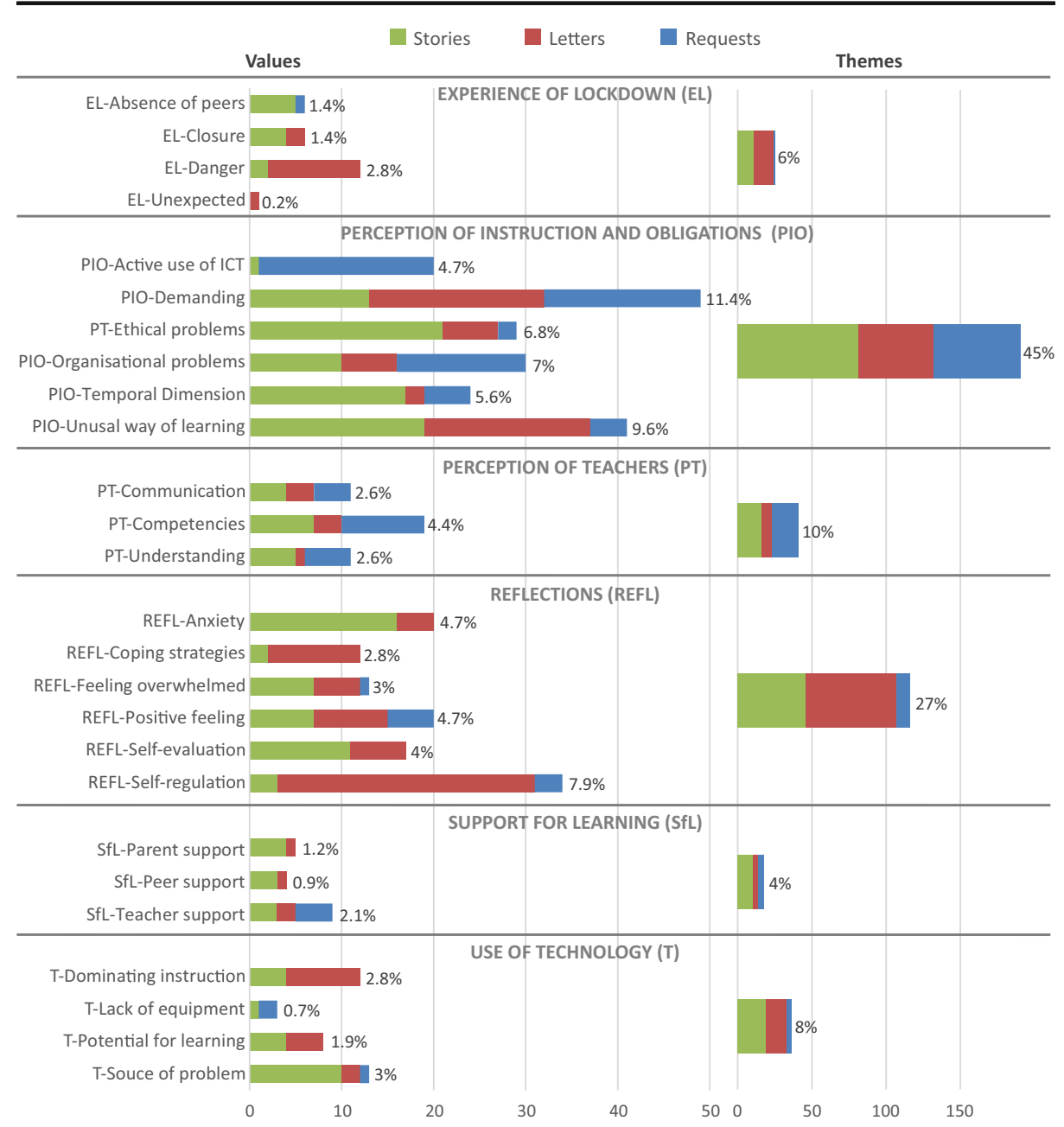

Fig. 1 Frequencies and percentages of values and themes by genre identified in the narrative units. Bars show frequencies ( $x$ axis) of units within each value (left side) and theme (right side) expressed through the three genres. Percentages outside of bars show the share of each value and theme in the total of all units

wrote: "Our teachers gave us much more homework than in regular school", "Be prepared for a lot of homework" or "(...) not to ask so much to be transcribed because it is tiring". Also, in their perception, students often compared the new, unusual, and the old, regular learning experience and wrote: "knowledge that we would otherwise surely pick up from school, we do not get this way" or "...but it is much more difficult to learn without mutual interaction (...) without additional explanations that are possible during classical teaching".

Students' reflections (cluster 2) involve reflections on both affective states and more cognitive ones, displaying and using a wide array of stances to reflect on their self-oriented activities to act upon the perceived challenges in the learning context. Expressions about the need for self-regulatory behaviour were prominent—students wrote: "Accept the obligations immediately, do not hesitate", "pay attention in the class, so you can answer if the teachers ask you something" or "so I made an effort and did all the homework". Other reflexive expressions 


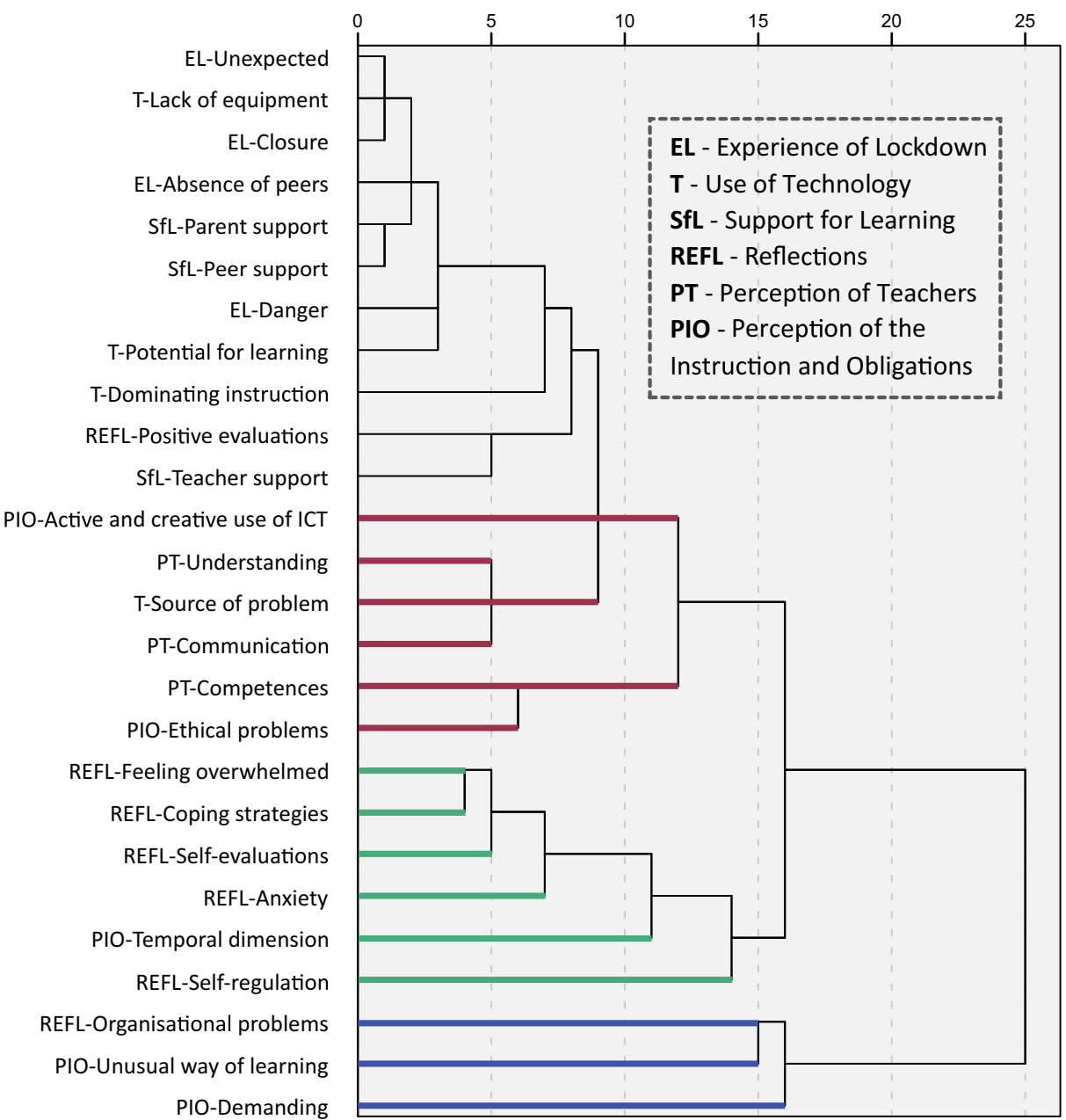

Fig. 2 Metanarrative dendrogram

included sharing anxiety, such as "Over time, you may feel empty, lonely, stupid, and even depressed", feeling overwhelmed “And I really don't know how I'm going to do this every day", and coping "Despite all this, we will go through these times, don't let that stop you from enjoying life even though it's hard". This cluster also includes expressions of positive evaluations of the experience such as "I liked this way of working, the experience was interesting with all this". Additionally, mentions of time pressure and need to keep up with deadlines have been clustered into cluster 2 as well, such as "prohibit sending emails/ messages/homework/assignments between 8pm and 8am".

Representation of the "other" (cluster 3) subsumes a rich bouquet of expressions highlighting teachers' competencies ("... she didn't know how to turn the microphone on"), their communication skills ("Reply to emails, for God's sake!"), and their understanding and compassion ("Don't get so angry if the kids don't get to do everything"), and technologies as a source of problem in the distant learning classes ("Sometimes due to a technical error we couldn't submit homework to the platform"). The same cluster also includes concerns with 
ethical problems in the unusual situation, such as "(...) the professor accused me of copying, which I didn't do" or "Cheating in online school is much easier". Furthermore, students pinpoint an important contradiction between new technology and old pedagogy and share a plea for a more active and creative use of ICT. For example, they requested "Teachers could do some interesting quizzes or tests, some assignments that might actually motivate students to learn". Relatively unrelated to the three clusters described above and much less prominent than the previous, stand narratives with units dwelling on different aspects of the lockdown experience, such as "Dear friend, the situation is serious ... save yourself to save others" or "and it's a bad thing I didn't get to see my friends". Also, mentions of support for learning remained unrelated to other values, whereby students referred more often to teachers for support ("if we didn't understand something, we could ask for help"), than to parents ("but don't let this scare you because you have your family by your side") and peers ("I asked a very good friend from my class to help me and we did a nice job"). Diverse attitudes to the technologies used in the process were also mentioned, such as lack of equipment (e.g. "not all students have adequate conditions for learning"), potential for learning (e.g. "the experience was good because I acquired new skills through the Internet and social media"), and the ways technology was dominating the instruction (e.g. "Teachers used Edmodo, Google Classroom, and Gmail for communication with students").

\section{Genre differences}

The dynamic storytelling methodology is built on the expectation that participants will use different genres to communicate partly different thoughts, feelings, or accounts, and that only combining the narratives disclosed in a variety of genres can provide a more complete picture (Daiute \& Kovač-Cerović, 2017). ANOVA conducted on binarized data showed that 11 out of 26 codes had significantly different occurrences in different genres: danger $(F(2106)=3.56, p$ $<.05)$, make full use of ICT $(F(2106)=10.29, p=.00)$, time references $(F(2106)=3.66, p<$ $.05)$, unusual way of schooling $(F(2106)=6.51, p=.00)$, ethical issues $(F(2106)=4.01, p<$ $.05)$, anxiety and concerns $(F(2106)=9.42, p=.00)$, self-evaluations $(F(2106)=5.68, p=$ $.00)$, self-regulation $(F(2106)=28.15, p=.00)$, coping strategies $(F(2106)=6.54, p=.00)$, domination of technology $(F(2106)=6.96, p=.00)$, and problems caused by the use of technology $(F(2106)=4.79, p=.00)$. Means for these codes per each genre are given in Fig. 3 .

The LSD post hoc test revealed that students' expressions regarding the use of technology and their anxiety and concerns, and the time references were more prevalent when narrating through stories than in the other two genres. Notions of a new dangerous reality, coping methods, and self-regulation, as well as notions of the domination of technology emerged more frequently in letters than in the other two genres, while appeals for making full use of ICT appeared more often in requests for teachers than in the other two genres. Additionally, stories and letters had significantly more mentions of the novel ways of schooling and selfevaluation than did requests, and ethical issues were more common in stories than in requests.

These findings corroborate our expectations that a multigenre approach, inviting the expression of thoughts, feelings, and experiences from different positions and stances created by the genre-specific prompts, would assemble a broader and more articulate picture and understanding of participants' perspectives in a situation burdened by ambiguity, uncertainty, and an urgent need for sensemaking such as the school lockdown in 2020. We find the contribution of the less traditional genres (letters and requests) in combination with stories especially reinforcing for the multigenre methodology. For instance, the important reference to self-regulation would not have surfaced without students being 


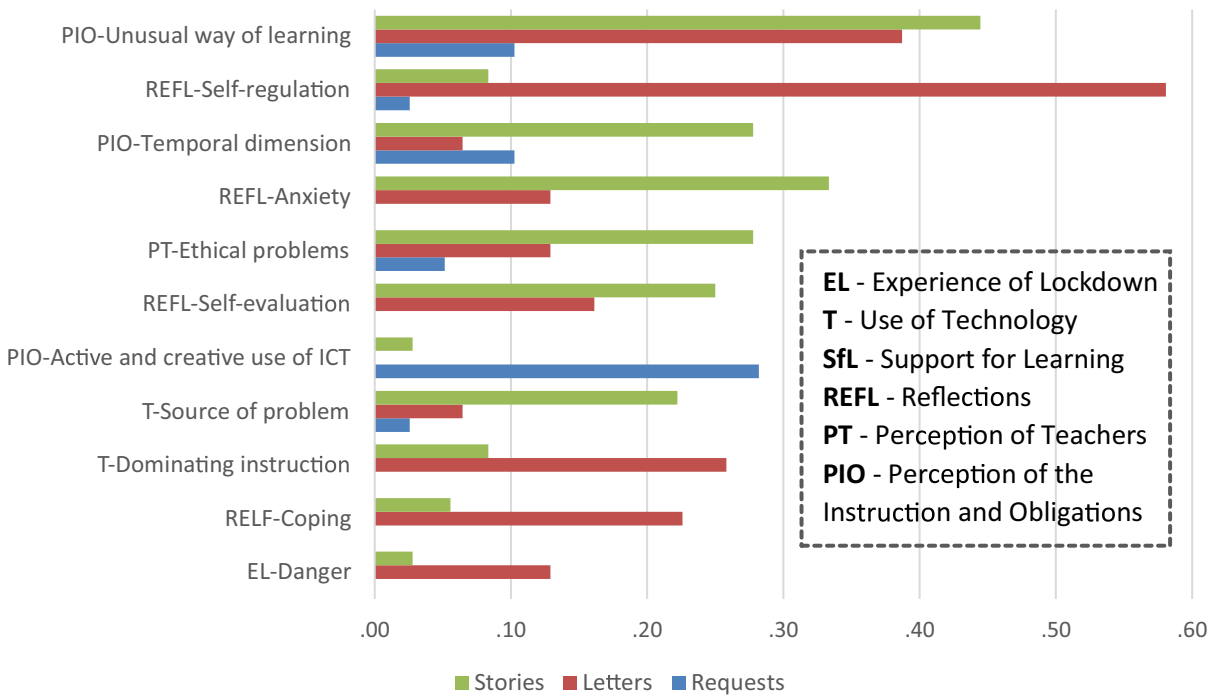

Fig. 3 Detected genre differences in the occurrence of value codes. The figure presents the 11 values where genre differences were detected. Genre differences were not detected regarding the 15 values not presented

prompted to share their advice with peers in a letter format, nor would the strong voices of children asking for a cognizant use of ICT have appeared without the prompt to write a request to teachers.

\section{Demographic differences}

Differences between genders, age, and type of school did not come across as important variables explaining the types of responses obtained from the narratives. The effect was examined for gender, level of education (primary and secondary), and type of school (elementary G1-G8, upper secondary general school, and vocational school) on binarized data.

Regarding gender, only two values showed significant effects: positive evaluations $(t(21)=$ 2.16, $p<.05)$ and mentions of teachers' support for learning $(t(21)=2.16, p<.05)$, occurring only in girls' narratives. Positive evaluations were expressed only by elementary school students, leading to the only significant difference regarding the age of students $(t(15)=$ 2.24, $p<.05)$. School type had an effect on the occurrence of expressions of concerns regarding ethical issues $(F(2.29)=5.31, p<.05)$ and mentions of peer support in learning $(F(2.29)=4.53, p<.05)$. LSD post hoc tests showed more expressions of concerns with ethical issues in narratives of students in general secondary schools $(M=.71, S D=.49)$ than in narratives of elementary school students $(M=.13, S D=.34)$ or those in vocational schools $(M$ $=.22, S D=.44$ ). Similarly, peer support seemed to be more important to students in general secondary schools, since the narratives of other students did not include this issue.

\section{Discussion}

The most important finding of our narrative analysis is the richness, complexity, and nuance enacted through diverse narrative expressions. The 6 themes and 26 values, albeit differing in frequency, shine through the narratives and allow us to take a glimpse at the experience of 
children during school closure through their own eyes, through the multidimensional conceptual matrix they employed while communicating their experiences.

Talking about their experience, children position their accounts along the themes unevenly. Two seem pivotal in the accounts of more than $80 \%$ of children: what kind of school is this? and how do I deal with it?, while two others occur less frequently (in the narratives of around half of the children): a dialogue with the teacher mediating the curriculum and exploration of the new tool, i.e. of the technology mediating learning. Surprisingly, the areas of experience that might have been expected from an adult perspective - such as obtaining support for learning from others, or the scary experience of the lockdown itself-were rarely mentioned. As the harsh and scary lockdown was already abolished at the time of our research, students focused more on the school closure experience.

A particularly striking aspect in the complexity of this multidimensional account of the children's experience is the nuanced positioning of the children's expressions, pleas, evaluations, reflections, and feelings around each of the themes in a multitude of ways, highlighting their diverse and dynamic structure. For example, when describing the new learning environment, students would concurrently stress its organizational aspects, demanding content and tasks, ethical dilemmas, and strict timeframes, and comment on not making full use of the potential of ICT for learning. Similarly, students' self-reflections expressed through the three genres embrace a wide range of cognitive and emotional, positive and negative, and regulative and evaluative reflections, including both anxiety and joy; technologies are expressed as origins of problems or elements of learning potential, lacking or dominating; teachers come up for their communication style, understanding, and competence (or lack thereof), again from multiple angles.

A cluster analysis, conducted in order to further structure our findings from the narrative analysis, additionally supported the key points. We found two clusters, roughly corresponding to students' expressions about the complexities of the learning situation encountered and the richness of their positioning towards it and reflection on it; and a third cluster, qualifying the engagement with teachers in their new role in the digital environment, and the engagement with the technology itself, for the first time used for learning rather than social and entertainment purposes. The cluster analysis, albeit helping provide a more parsimonious structure of the children's experiences, retained the multitude, nuances, and complexities of the value expressions that formed the three metanarratives.

This richness, gained through the narrative and multigenre approach, overrides and renders simplistic one-dimensional accounts of students' experience in the new world of online learning and distance education, and calls for further research. Offering children the opportunity to narrate in different genres enables different psychological processes as well as different levels of vulnerability in the expression (Daiute, 2021). Different audiences implied by each genre allow for distinct aspects of the experience to become salient and communicated in a manner adjusted to the implied recipient (Jović, 2020). The diversity of genre differences, as expected based on previous research using a similar methodology (Daiute \& Kovač-Cerović, 2017; Daiute et al., 2020), indeed contributed to the richness of the results in the present study as well. Stories most often conveyed concerns and anxieties, ethical problems, and time references. Letters were the medium in which students described to peers the unusual features of the experience, emphasized the importance of self-regulated learning, and gave advice on coping strategies. Schoolchildren used requests mainly to stress the importance of making full use of the opportunities that ICT provides for teaching and giving up on traditional methods. 
The differences in emphasis gained through using different genres of expression can serve as a methodological recommendation for further multigenre narrative research.

Some of our more specific findings are more expected than others. For example, expressions on how demanding instruction was, of feeling overwhelmed by the overload of digital content and excessive tasks and homework, are fully coherent with findings from other countries reported by Niemi and Kousa (2020), Bubb and Jones (2020), \& Pelikan et al. (2021). Similarly, self-regulation, which is repeatedly reported on and theorized as highly relevant for successful distance education by researchers (OECD, 2020; Pelikan et al., 2021), also comes through as pivotal in the narratives of our students. Technological problems as pinpointed by other researchers (e.g. Adnan \& Anwar, 2020) are often mentioned as well.

Our students spotlight surprisingly clearly the ethical aspect of distance education, regarding the assessment of learning outcomes. Their expressions point to a keen understanding, problematizing, and engaging with the issue of what fair assessments should/could look like under circumstances when usual rules are unenforceable and thus open the space for a discussion broader than the pandemic, tapping into questions of education quality. Similarly, students' expressions show that, although online instruction and distance learning forced teachers to use new technologically mediated teaching solutions, teachers did not abandon their traditional, knowledge transmission-oriented teaching practices. Instead of using the new tool to rethink education (Reimers \& Schleicher, 2020; Zhao, 2020), teachers rather assimilated the new tool into their old practice.

Issues of organization and time came across much more strongly than expected. In regular school, organizational and timing issues are under the auspices of school authorities or governments, and children are rarely invited to discuss them. In the new digital situation, this area of school life opened up for the students, and they grabbed the opportunity to understand and cope with but also to try to reorganize and request to have a legitimate say in these newly discovered aspects of schooling.

Several recommendations for policy, practice, and research can be drawn from the results. Although our sample is small and consists only of students from Serbia, their strong and multifocal opinions resonate with emerging requests to use the COVID-19 global education crisis for rethinking education (e.g. OECD, 2020; Zhao, 2020). The narratives demonstrate students assuming a more active role in the choice of learning content, methods, activities, organization, and timeframes. They used the experience of distance education to develop more profound self-regulation and call for reshaped, more collaborative roles and relationships with teachers, not only in the digital environment but also in a future, post-pandemic education. These micro-level change processes require nurturing, but also positive take-up by policymakers. Creating collaborative spaces for regularly sharing students' experiences of schooling during the pandemic and after with their teachers, parents, and school administrations would be the first step towards participatory policymaking that involves and respects students' voices. It should be followed by joint initiatives and collaborative agreements on better, more constructive and less stressful school practices in the future.

Moreover, our research strongly argues in favour of keenly and regularly exploring students' experiences in any education setting-soliciting their views, hearing their voices, reactions, reflections, and actions. This is especially important in circumstances where live interaction is scarce and known routines are ruptured, such as in emergency distance education, but is equally recommended in non-emergency situations. Almost 30 years after endorsing the child rights convention internationally 
(United Nations, 1989), full participation of students in issues affecting their life prospects and everyday wellbeing should not be negotiable.

It was clear from the accounts of our students that digital competencies of both teachers and students are underdeveloped. Therefore, it is an imperative to rapidly ensure mechanisms upgrading these competencies, much beyond what conventional teacher training courses can deliver. Building on the acquired, (however fragile) new competencies, it seems a sound recommendation to purposefully continue schooling through hybrid models, that embrace live teacher-student and student-student social interactions which provide indispensable feedback and guidance for both learners and teachers (Hargreaves \& Fullan, 2020), but also create space for further developing the skills for education through digital media.

Our findings show that learning cannot simply be "moved" from the school to the homenew content, new pedagogy, and new ways of monitoring and assessment are required for distance education to provide quality (UNESCO, 2020). Such transformation cannot solely rest on the shoulders of teachers. Hence, a further recommendation building on what our students perceived in online education, reacted to and reflected about, would go to ministries and curriculum bodies: to provide a variety of high-quality digitalized education content modules, coupled with meaningful student assignments from which teachers could choose and use in their online classes.

We found that, although rarely, some students faced more difficulties than others. Teachers and schools should make sure that their hardships do not go unnoticed and take steps to use the flexibility of distance education to individualize instruction toward them. Also, accessibility of online learning and equity of education should always be considered, and measures are taken to ensure the participation of those who lack technical resources, by supplying them with equipment, adjusting the schooling processes, and providing ample encouragement and support.

The limitations of our research derive not only from possible specificities of the Serbian imperfect context but also from the fact that the data collection method applied in our study excluded students who did not have access to the internet and/or adequate device. Therefore, future studies should try reaching these students and gain insight into their views. A more general limitation of our study stems from its timespan. In this article, we not only address a dynamically evolving research area but the object of our research is also changing in dynamic and often unforeseen ways; hence, we cannot claim that our results focused on the first school closure in Spring 2020 will prove valid in the months to come. Schools are closed, reopened, and closed again, dictated by the pandemic, and school practices in emergency distance education evolve and develop, and students and teachers acquire strategies to cope with the new situation and build new understandings. Nevertheless, illuminating schoolchildren's narrated experiences, as proven through our current research, is hopefully a lasting asset.

\section{Conclusion}

The current study aimed to explore how schoolchildren experienced distance learning and to contribute to the body of research spurred by the COVID-19 crisis in education. To this end, we collected students' narratives about the novel way of schooling in three different genres (stories, letters, and requests), and applied an inductive value analysis, with further quantitative analyses for looking into patterns in our data. Most salient in students' narratives were mentions of different features of the instruction and obligations that students found demanding 
and unusual, and they expressed concern regarding organization, timeframes, ethical issues, and the underuse of ICT potential in online teaching. Students shared their affective and cognitive reflections, describing anxiety, feeling overwhelmed, positive evaluations, selfregulatory behaviours, self-evaluations, and coping strategies, witnessing the strong effect of the new situation on children's self-reflection. Students' perceptions of their teachers were in regard to the quality of communication, understanding, and their competence. Besides dominating instruction, technologies were not only seen as a potential for learning but also as a source of various problems in teaching, with the lack of equipment being one of them.

An important point arises from this and hopefully similar research tapping into the complexities of the children's experiences: we can see children as actively participating in structuring their life and experiences, assuming also a critical, problematizing role of rethinking what education should be. In this vein, their voices echo the scholarly initiatives for reinventing education based on the experience of the pandemic, such as Zhao (2020) \& Azorín (2020), and demonstrate capacity for being on the highest levels of the ladder of participation (Hart, 1992).

Based on our findings, we recommend granting students a more active role in learningrelated choices, creating cooperative niches for participatory school policymaking, more relevant support in providing digital teaching materials, and promoting ICT competences of both students and teachers, while considering hybrid models of schooling to maintain live interactions. We stress the importance of reaching students without access to the online world and recommend considering multigenre narrative research for obtaining complex understandings of participants' experiences.

\section{References}

Adnan, M., \& Anwar, K. (2020). Online learning amid the COVID-19 pandemic: Students' perspectives. Online Submission, 2(1), 45-51. https://doi.org/10.33902/JPSP.2020261309.

Azorín, C. (2020). Beyond COVID-19 supernova. Is another education coming? Journal of Professional Capital and Community, 5(3-4), 381-390. https://doi.org/10.1108/JPCC-05-2020-0019.

Bakhtin, M. (1986). The problem of speech genres. In C. Emerson \& M. Holquist (Eds.), Speech genres and other late essays (pp. 60-102). University of Texas Press.

Bal, I. A., Arslan, O., Budhrani, K., Mao, Z., Novak, K., \& Muljana, P. S. (2020). The balance of roles: Graduate student perspectives during the COVID-19 pandemic. TechTrends, 64(6), 796-798. https://doi.org/10.1007/ s11528-020-00534-z.

Bamberg, M. (2004). Positioning with Davie Hogan: Stories, tellings, and identities. In C. Daiute \& C. Lightfoot (Eds.), Narrative analysis: Studying the development of individuals in society (pp. 135-157). Sage.

Bates, T. (1993). Theory and practice in the use of technology in distance education. In D. Keegan (Ed.), Theoretical Principles of Distance Education (pp. 183-201). Routledge.

Bubb, S., \& Jones, M. A. (2020). Learning from the COVID-19 home-schooling experience: Listening to pupils, parents/carers and teachers. Improving Schools, 23(3), 209-222. https://doi.org/10.1177/ 1365480220958797.

Creswell, J. W., \& Poth, C. N. (2016). Qualitative inquiry and research design: Choosing among five approaches. Sage.

Daiute, C. (2008). The rights of children, the rights of nations: Developmental theory and the politics of children's rights. Journal of Social Issues, 64(4), 701-723. https://doi.org/10.1111/j.1540-4560.2008.00585.x.

Daiute, C. (2013). Narrative inquiry: A dynamic approach. Sage.

Daiute, C. (2021). Narrating crisis from war zones to disease zones. Journal of Humanistic Psychology, 61(2), 219-230. https://doi.org/10.1177/0022167820964329.

Daiute, C., \& Kovač-Cerović, T. (2017). Minority teachers: Roma in Serbia: Narrate education reform. Institute of Psychology. 
Daiute, C., Kovács Cerović, T., Mićić, K., Sullu, B., \& Vracar, S. (2020). Dynamic values negotiating geopolitical narratives across a migration system. Qualitative Psychology, 7(3), 367-383. https://doi.org/10. $1037 /$ qup0000166.

Dhawan, S. (2020). Online learning: A panacea in the time of COVID-19 crisis. Journal of Educational Technology Systems, 49(1), 5-22. https://doi.org/10.1177/0047239520934018.

Fickermann, D. \& Edelstein B. (Eds.) (2021). Schule während der Corona-Pandemie Neue Ergebnisse und Überblick über ein dynamisches Forschungsfeld [School during the corona pandemic new results and overview of a dynamic field of research]. Waxmann. https://doi.org/10.31244/9783830993315

Greenhalgh, T., Robert, G., Macfarlane, F., Bate, P., Kyriakidou, O., \& Peacock, R. (2005). Storylines of research in diffusion of innovation: a meta-narrative approach to systematic review. Social Science \& Medicine, 61(2), 417-430. https://doi.org/10.1016/j.socscimed.2004.12.001.

Guetterman, T. C. (2015). Descriptions of sampling practices within five approaches to 22 qualitative research in education and the health sciences. Forum: Qualitative Social Research, 16(2), 25. https://doi.org/10.17169/ fqs-16.2.2290.

Hargreaves, A., \& Fullan, M. (2020). Professional capital after the pandemic: Revisiting and revising classic understandings of teachers' work. Journal of Professional Capital and Community, 5(3-4), 327-336. https:// doi.org/10.1108/JPCC-06-2020-0039.

Hart, A. (1992). Children's participation: From tokenism to citizenship. UNICEF International Child Development Centre.

Hilppö, J., Rainio, A., Rajala, A., \& Lipponen, L. (2020). Children and the COVID-19 lockdown: From child perspectives to children's perspectives. Cultural Praxis. http://culturalpraxis.net/wordpress1/2020/04/26/ children-and-the-covid-19-lockdown-from-child-perspectives-to-childrens-perspectives/.

Institute of psychology. (2020). Praćenje načina učešća i procesa učenja učenika iz osetljivih grupa tokom ostvarivanja obrazovno-vaspitnog rada učenjem na daljinu [Monitoring the participation and learning process of students from vulnerabile groups during online education]. Ministry of Education, Science, and Technological Development of the Republic of Serbia, Institute of psychology \& UNICEF.

Jović, S. (2020). "They have been in both positions": Narrative exploration of adolescents' sense-making about injustice from the positions of the object and subject of injustice. Qualitative Psychology, 7(3), 285-305. https://doi.org/10.1037/qup0000142.

Kim, L. E., \& Asbury, K. (2020). 'Like a rug had been pulled from under you': The impact of COVID-19 on teachers in England during the first six weeks of the UK lockdown. British Journal of Educational Psychology, 90(4), 1062-1083. https://doi.org/10.1111/bjep.12381.

Kirsch, C., Engel de Abreu, P. M. J., Neumann, S., Wealer, C, Brazas, K., \& Hauffels, I. (2020). Subjective wellbeing and stay-at-home-experiences of children aged 6-16 during the first wave of the COVID-19 pandemic in Luxembourg: A report of the project COVID-Kids. University of Luxembourg.

Kovac Cerovic, T., Grbic, S., \& Vesic, D. (2018). How do schools integrate refugee students? In: F. Dovigo (Ed.) Challenges and opportunities in education for refugees in Europe: From research to good practices (pp. 77112). Brill Sense. https://doi.org/10.1163/9789004383227_005.

Ministry of Education, Science, and Technological Development of the Republic of Serbia (2020a). Stručno uputstvo za organizaciju i realizaciju obrazovno-vaspitnog rada u osnovnoj školi u školskoj 2020/2021. godini[Instructions]. http:/www.mpn.gov.rs/wp-content/uploads/2020/08/strucno-uputstvo.pdf.

Ministry of Education, Science, and Technological Development of the Republic of Serbia (2020b). Ostvarivanje obrazovno-vaspitnog rada učenjem na daljinu za učenike osnovnih i srednjih škola [Distance learning during the state of emergency]. http:/www.mpn.gov.rs/wp-content/uploads/2020/03/Nastava-na-daljinu-uvanrednom-stanju.pdf.

Moss, G., Allen, R., Bradbury, A., Duncan, S., Harmey, S., \& Levy, R. (2020). Primary teachers' experience of the COVID-19 lockdown-Eight key messages for policymakers going forward. UCL Institute of Education. https://discovery.ucl.ac.uk/id/eprint/10103669/.

Niemi, H. M., \& Kousa, P. (2020). A case study of students' and teachers' perceptions in a Finnish high school during the COVID pandemic. International Journal of Technology in Education and Science (IJTES), 4(4), 352-369. https://doi.org/10.46328/ijtes.v4i4.167.

OECD. (2020). Strengthening online learning when schools are closed: The role of families and teachers in supporting students during the COVID-19 crisis. http://www.oecd.org/coronavirus/policy-responses/ strengthening-online-learning-when-schools-are-closed-the-role-of-families-and-teachers-in-supportingstudents-during-the-covid-19-crisis-c4ecba6c/.

Patton, M. Q. (2002). Qualitative research and evaluation methods (3rd ed.). Sage.

Pavlovic Babic, D., Baucal, A. (2013). Podrži me, inspiriši me: PISA 2012 prvi rezultati [Support me, inspire me: PISA 2012 first results]. Institut za psihologiju. 
Pelikan, E.R., Lüftenegger, M., Holzer, J., Korlat, S., Spiel, C., \& Schober, B. (2021). Learning during COVID19: the role of self-regulated learning, motivation, and procrastination for perceived competence. Zeitschrift für Erziehungswissenschaft, Advance online publication. https://doi.org/10.1007/s11618-021-01002-x,

Reimers, F. M., \& Schleicher, A. (2020). Schooling disrupted, schooling rethought: How the Covid-19 pandemic is changing education. OECD. https://read.oecd-ilibrary.org/view/?ref=133_133390-1rtuknc0hi\&title= Schooling-disrupted-schooling-rethought-How-the-Covid-19-pandemic-is-changing-education

Rumble, G. (2001). Re-inventing distance education, 1971? International Journal of Lifelong Education, 20(12), 31-43 https://www.tandfonline.com/doi/abs/10.1080/02601370010008246.

Tartavulea, C. V., Albu, C. N., Albu, N., Dieaconescu, R. I., \& Petre, S. (2020). Online teaching practices and the effectiveness of the educational process in the wake of the COVID-19 pandemic. Amfiteatru Economic, 22(55), 920-936. https://doi.org/10.24818/EA/2020/55/920.

UNESCO (2020). Education: From disruption to recovery. Retrieved October 19, 2020, from https://en.unesco. org/covid19/educationresponse.

UNICEF (2020). Going back to school during the COVID-19. - Voices of children. https://www.unicef.org/ georgia/stories/going-back-school-during-covid-19-voices-children.

Union of Highschool Students of Serbia (2020). Da li je neko obratio pažnju na srednjoškolce i zašto ne: Pregled srednjoškolskog života tokom pandemije [Did someone pay attention to highschoolers and why not: A review of highchoolers' life during pandemic]. https://javnozagovaranje.bos.rs/vesti/137/da-li-je-nekoobratio-paznju-na-srednjoskolce-i-zasto-niko-nije-html

United Nations. (1989). Convention on the rights of the child. Treaty series, 1577, 3 https://www.refworld.org/ docid/3ae6b38fo.html.

Zhao, Y. (2020). COVID-19 as a catalyst for educational change. Prospects, 49(1-2), 29-33. https://doi.org/10. 1007/s11125-020-09477-y.

Zittoun, T. (2006). Transitions: Symbolic resources in development. Information Age Publishing.

Publisher's note Springer Nature remains neutral with regard to jurisdictional claims in published maps and institutional affiliations.

Tünde Kovács Cerović. Faculty of Philosophy, University of Belgrade, Belgrade, Serbia

Current themes of research:

Inclusive education, children from disadvantaged background, corruption in education, systems, and school reforms.

Most relevant publications in the field of Psychology of Education:

Daiute, C., Kovács Cerović, T., Mićić, K., Sullu, B., \& Vracar, S. (2020). Dynamic values negotiating geopolitical narratives across a migration system. Qualitative Psychology, 7(3), 367-383. https://doi.org/10. 1037/qup0000166

Kovac Cerovic.T., Grbic, S. \& Vesic, D. (2018). How do schools integrate refugee students? In: F. Dovigo (Ed.) Challenges and opportunities in education for refugees in Europe: From research to good practices. Leiden/ Boston: Brill Sense

Daiute, C. and Kovač-Cerović,T. (2017). Minority teachers - Roma in Serbia - Narrate education reform. Belgrade: Institute for Psychology

Kovač-Cerović,T. \& Vulic, I. (2016). Supporting education of refugee and migrant children and youth. New York, NY: ESP Working Paper Series, 2016 No. 76.

Kovač Cerović, T., Jovanović, O. \& Pavlović Babić, D. (2016). Individual education plan as an agent of inclusiveness of the educational system in Serbia: Different perspectives, achievements, and new dilemmas. Psihologija 2016, Vol. 49(4), 431-445. DOI: 10.2298/PSI1604431K

Daiute, C., Ataman, A. \& Kovacs-Cerovic, T. (2015). Minority educators discuss a public story that challenges social inclusion. Language, culture and social interaction, 7, 109-125. doi:10.1016/j.lcsi.2015.10.002

Kovač-Cerović,T., Vizek-Vidović, V., Powell, S. (2011): Parent participation in the life of the school in South East Europe. Ljubljana: Center for Education Policy Studies, Faculty of Education.

Burnett, N., Darvas, P. Kovacs-Cerovic, T et al. (2004): Needs assessment: Summary report. A background document prepared for the Roma Education Fund Donors' Conference. Washington, DC: World Bank 
Katarina Mićić. Faculty of Philosophy, University of Belgrade, Belgrade, Serbia. katarina607@ gmail.com

Current themes of research:

Inclusive education, sociocultural aspects of learning, equity issues in education, and mathematics education.

Most relevant publications in the field of Psychology of Education:

Daiute, C., Kovács Cerović, T., Mićić, K., Sullu, B., \& Vracar, S. (2020). Dynamic values negotiating geopolitical narratives across a migration system. Qualitative Psychology, 7(3), 367-383. https://doi.org/10. 1037/qup0000166

Daiute, C., Kovacs Cerovic, T., Popovic, LJ., Sullu, B., \& Micic, K. (2019, Semptember 2-6). Policy echoes and importantly unique positions within narratives in schools including refugees along the Balkan Route. [Conference presentation]. European Conference on Educational Research: 'Education in an Era of Risk the Role of Educational Research for the Future', Hamburg.

Vračar, S., Mićić, K., Kovács Cerović, T \& Petrović, D. (2020, September 25-26). Exploring the intercultural sensitivity of Serbian children in the context of inclusion of migrant children in the national school system. [Conference presentation abstract]. 16th International Conference Days of applied psychology 2020, Niš.

Mićić, K., Vračar, S., \& Skočajić, M. (2020, September 25-26). Students' experiences of online schooling during the 2020 Spring lockdown in Serbia. [Conference presentation abstract]. 16th International Conference Days of applied psychology 2020, Niš.

Simić, N., \& Mićić, K., (2020, October 15-18). High school students' achievement and motivation in mathematics - do gender and gender role identification play a role? [Conference presentation abstract]. XXVI scientific conference empirical studies in psychology.

Mićić, K., Vračar, S., \& Jokić Zorkić, T. (2021, March 12-13). Multižanrovska analiza narativa u cilju unapređenja obrazovnih politika. [Conference presentation abstract]. Knjiga rezimea s XXVI naučne konferencije „Pedagoška istraživanja i školska praksa“ Kvalitativna istraživanja kroz discipline i kontekste: osmišljavanje sličnosti i razlika, Beograd.

Mićić, K., Kovács Cerović, T., \& Vračar, S. (2020, September 21). The dark past and a brighter future - migrant students' academic motivation and experiences with schooling in Serbia. [Conference presentation abstract]. Online Event "Cross-Border Perspectives on Refugee Education", Wien.

Selena Vračar. Faculty of Media and Communications, Singidunum University, Belgrade, Serbia

Current themes of research:

Inclusive education, instructional leadership, and intercultural education.

Most relevant publications in the field of Psychology of Education:

Vračar, S. i Mandić, D. (2019, januar). Profesionalni razvoj direktora škola - otvoreno pitanje u obrazovnom sistemu. "Obrazovna politika i praksa: u skladu ili u raskoraku?", Beograd.

Petrovic S. D \& Vracar, S. (2019). Understanding and defining instructional leadership: School principals' perspective, InPACT Conference, Zagreb, 2019. Zagreb.

Marušić Jablanović, M. i Vračar, S. (2019). Ispitivanje motivacije nastavnika iz Srbije za izbor zanimanja primenom FIT-Choice skale (Exploring Serbian teachers' motivation for teaching with the application of FIT-Choice Scale). Zbornik Instituta za pedagoška istraživanja, 51(1), 7-45.

Daiute, C., Kovács Cerović, T., Mićić, K., Sullu, B., \& Vracar, S. (2020). Dynamic values negotiating geopolitical narratives across a migration system. Qualitative Psychology, 7(3), 367-383. https://doi.org/10. 1037/qup0000166.

Vračar, S., Mićić, K., Kovács Cerović, T \& Petrović, D. (2020, September 25-26). Exploring the intercultural sensitivity of Serbian children in the context of inclusion of migrant children in the national school system. [Conference presentation abstract]. 16th International Conference Days of applied psychology 2020, Niš.

Mićić, K., Vračar, S., \& Skočajić, M. (2020, September 25-26). Students' experiences of online schooling during the 2020 Spring lockdown in Serbia. [Conference presentation abstract]. 16th International Conference Days of applied psychology 2020, Niš.

Mićić, K., Vračar, S., \& Jokić Zorkić, T. (2021, March 12-13). Multižanrovska analiza narativa u cilju unapređenja obrazovnih politika. [Conference presentation abstract]. Knjiga rezimea s XXVI naučne 
konferencije „Pedagoška istraživanja i školska praksa“ Kvalitativna istraživanja kroz discipline i kontekste: osmišljavanje sličnosti i razlika, Beograd.

Mićić, K., Kovács Cerović, T., \& Vračar, S. (2020, September 21). The dark past and a brighter future - migrant students' academic motivation and experiences with schooling in Serbia. [Conference presentation abstract]. Online Event "Cross-Border Perspectives on Refugee Education", Wien. 